\title{
Livro de Jó põe metafísica à prova
}

\author{
Mariângela Alves de Lima
}

F

$\mathrm{m}$ um livro que se tornou famoso (O Teatro e Seu Espaço), escrito em 1968, o encenador Peter Brook narra seu esforço para obter, por meio de vários experimentos, uma "expressão verdadeira”. Desde então, a idéia de representação cujo valor reside na autenticidade tornou-se um tanto fora de moda. Tanto quanto outras artes, o teatro de hoje se compraz no artifício, na exibição insistente de seus próprios processos de composição. Ao apresentar $O$ Livro de Jó, o grupo Teatro da Vertigem retoma a intrincada questão do debate entre arte e verdade que dominou os anos 60 .

Quem espera do teatro uma noite agradável, um motivo para discorrer sobre a excelência dos intérpretes ou do texto, não encontrará muita satisfação neste espetáculo. Em vez de objeto a ser contemplado, há uma experiência de tal ordem que só nos resta aceitá-la ou rejeitá-la como um todo. Jó, sua mulher e seus amigos não são personagens críveis, ancorados no substrato histórico do Antigo Testamento. Não podemos contemplá-las à distância porque são apresentadas como porta-vozes de um diá- logo que cada um de nós já trava com o criador em momentos de angústia.

O texto recriado por Luiz Alberto de Abreu e a encenação, dirigida por Antônio Araújo, se inspiram nos procedimentos alegóricos do teatro medieval. O que vemos não é o indivíduo, mas uma abstração ou uma alma. Nada encobre este núcleo metafísico, investigado pela consciência. Elementos narrativos como a queda e a revolta são mais tênues do que o teor do diálogo.

Não há dúvida de que o espetáculo tem pesado revestimento material. Atravessamos o equipamento hospitalar, sentimos o odor de um resquício de desinfetante e seguimos as pegadas sangrentas de Jó. Com isso, lembramos de um lugar onde se põe à prova a frágil carcaça humana. Mas este espetáculo faz mais do que isso: transcende a dualidade entre corpo e espírito e propõe, com uma verdade que não conseguimos ignorar, um admirável combate.

(O Estado de S. Paulo, 17/02/1995)

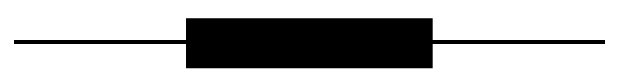

Mariângela Alves de Lima é crítica do jornal O Estado de S. Paulo e pesquisadora. 